\title{
An Approach to The Acute Phase of Chagas' Disease: The Continuing Challenge it Presents in the $21^{\text {st }}$ Century
}

\author{
Dário C. Sobral Filho ${ }^{1,2}$ \\ Universidade de Pernambuco - Cardiologia, ${ }^{1}$ Recife, PE - Brazil \\ Memorial Coração - Cardiologia, ${ }^{2}$ Recife, PE - Brazil \\ Short Editorial related to the article: Cardiac Evaluation in the Acute Phase of Chagas' Disease with Post-Treatment Evolution in Patients \\ Attended in the State of Amazonas, Brazil
}

Chagas disease, in addition to being widespread on the American continent with around six million persons infected, is currently present in various regions of the world as a result of the migration of individuals with the disease..$^{1,2}$

The statistics show that the incidence of acute cases has fallen from 700,000 new cases in 1990 to the current estimate of 29,000 - 30,000 per year by vector-borne transmission, plus 8,000 other cases by other modes such as transfusion and the digestive tract, owing to ingestion of food contaminated by Trypanosoma cruzi, ${ }^{2}$ as described by Ortiz et al. ${ }^{3}$ in their publication in this journal, in which they report 63 cases of cases of the acute form of Chagas disease in the state of Amazonas over a period of eight years, with oral transmission in $75 \%$ of the patients.

Despite the significant annual fall in its incidence and prevalence in the Americas, Chagas disease remains a serious public health problem, causing the death of approximately 12,000 persons per year. It also has a high socioeconomic cost, recently estimated at 500 million dollars in Latin America, with an annual loss of 770,00 life-years (adjusted) per premature death or loss of productive years resulting from physical disability. ${ }^{4}$

The slow progression of laboratory methods of diagnosis and of the development of new, more efficacious drugs, better tolerated by the patient, as well as the precarious nature of public health policies aimed at the extinction of the disease cause it to be classified as a "neglected disease". 1,2,5,6 It is estimated that only $1 \%$ of the patients infected with $\mathrm{T}$ cruzi receive the appropriate diagnosis and treatment every year. ${ }^{2}$

The article by Ortiz et al. ${ }^{3}$ draws attention to some important facts: the first of these is the increased incidence of acute cases by oral transmission in the Amazon region, where acute cases

\section{Keywords}

Chagas Disease/epidemiology; Trypanosoma Cruzi; Chagas cardiomyopathy/epidemiology; Amazonian Ecosystem.

Mailing Address: Dário C. Sobral Filho •

Universidade de Pernambuco - Cardiologia - Rua dos Palmares, 262.

Postal Code 50100-060, Santo Amaro, Recife, PE - Brazil

E-mail: dsobral@cardiol.br, dario.sobral@upe.br

DOI: $10.5935 / a b c .20190035$ in isolation or during an outbreak have been recorded in familial micro-epidemics by oral transmission through food contaminated by triatomine or their stools. Other authors have highlighted the regional nature of the epidemic, ${ }^{1,7-10}$ noting that this form of transmission of the disease is much more effective than the vector mode of transmission.

The other aspect emphasized by those authors is the less aggressive effect of the disease on the heart, with a high percentage of the patients in their sample without any signs of myocarditis when assessed by electrocardiography $(70 \%$ normal) and transthoracic echocardiography (87\% normal). Despite the debatable limitations of these two methods for the detection of myocarditis, it is likely that peculiar regional features can account for these findings.

From the genotyping studies of T. cruzi, Ortiz et al. ${ }^{3}$ suggest that the lower prevalence of cardiac disorders in their patients may be related to the T. cruzi lineage known as TcIV found in outbreak patients, whose pathogenicity, albeit poorly understood, may have a lower morbidity when compared with the Tcll lineage found in other endemic areas. ${ }^{11}$

The application of new knowledge of genetics and longitudinal studies designed to test this hypothesis is likely to produce important information for the management of these patients.

Lastly, the findings of Ortiz et al. ${ }^{3}$ on the treatment of the acute phase of the treatment of Chagas disease with Benznidazole deserve to be emphasized. However, information on this subject is scanty, being based on nonrandomized studies with insufficient numbers of patients and observation time. Although the definition of the criteria for a cure remains controversial, there is currently a consensus that treatment with Benznidazole should be carried out in the acute forms of the disease and that the patient is likely to benefit in the long term. ${ }^{1,2,10,12}$

The small size of the sample, the relatively short period of follow-up and the adoption of substitute outcomes in the evaluation of the results are limitations occurring with some frequency in the publications on this subject and these considerations also apply to the study by Ortiz et al. ${ }^{3}$ Nonetheless the information presented is significant and may provide new information for improving the diagnosis and treatment of Chagas disease. 


\section{References}

1. Dias JC, Ramos AN Jr, Gontijo ED, Luquetti A, Shikanai-Yasuda MA, Coura JR, et al. 2nd Brazilian Consensus on Chagas Disease, 2015. Rev Soc Bras Med Trop. 2016;49(Suppl 1):3-60.

2. Organización Panamericana de la Salud. Guía para el diagnóstico y el tratamiento de la enfermedad de Chagas. Washington, DC: WHO/ PAHO; 2018.

3. Ortiz JV, Pereira BVM, Couceiro KN, Guerra MGV, Guerra JAO, Ferreira JMB. Avaliação cardíaca na fase aguda da Doença de Chagas com evolução pós tratamento em pacientes atendidos no Estado do Amazonas-Brasil. Arq Bras Cardiol. 2019; 112(3):240-246.

4. Lee B, Bacon KM, Bottazzi ME, Hotez PJ. Global economic burden of Chagas disease: a computational simulation model. Lancet Infect Dis. 2013;13(4):342-8

5. WHO - World Healt Organization. Enfermedades tropicales desatendidas. 66. ․ Asamblea Mundial De La Salud. Resolución WHA66.12, 2013.

6. Bartsch SM, Avelis CM, Asti L, Hertenstein DL, Ndeffo-Mbah M, Galvani A, et al. The economic value of identifying and treating Chagas disease patients earlier and the impact on Trypanosoma cruzi transmission._PLoS Negl Trop Dis. 2018;12(11):e0006809.
7. Shikanai-Yasuda MA, Carvalho NB. Oral transmission of Chagas disease. Clin Infect Dis. 2012;54(6):845-52.

8. OPAS - Organização Pan-americana da Saúde. Doença de Chagas: guia para vigilância, prevenção, controle e manejo clínico da doença de Chagas aguda transmitida por alimentos. Rio de Janeiro: OPAS/OMS; 2009. (Série de Manuais Técnicos, 12).

9. Chagas disease in Latin America: an epidemiological update based on 2010 estimates. Wkly Epidemiol Rec. 2015;90(6):33-43.

10. Terhoch CB, Moreira HF, Ayub-Ferreira SM, Conceição-Souza GE, Salemi VMC, Chizzola PR, et al Clinical findings and prognosis of patients hospitalized for acute decompensated heart failure: Analysis of the influence of Chagas etiology and ventricular function. PLoS Negl Trop Dis. 2018;12(2):e0006207.

11. Monteiro WM, Magalhães LK, de Sá AR, Gomes ML, Toledo MJ, Borges L, et al. Trypanosoma cruzi IV causing outbreaks of acute Chagas disease and infections by different haplotypes in the Western Brazilian Amazonia. PLoS One. 2012;7(7):e41284.

12. Pinto AY, Valente VC, Coura JR, Valente SA, Junqueira AC, Santos LC, et al Clinical follow-up of responses to treatment with benznidazol in Amazon: a cohort study of acute Chagas disease. Plos One. 2013;8(5):e64450. 